\title{
General characteristics of food in developing regions-a situational diagnostic assessment
}

\author{
Abelardo Avila-Curiel* \\ Nutrition Department, National Institute of Medical Sciences and Nutrition, Mexico City, Mexico
}

\begin{abstract}
Since the founding of the Food and Agriculture Organization of the United Nations in 1946, it has reported on the serious problem of hunger in the world and has undertaken various initiatives for eradicating this problem; however, they have ended in failure. The number of people suffering from hunger has increased from 500 to 800 million in a period of six decades, despite constant growth in world food production, which has been more than sufficient to cover the needs of all of humanity since the 1970s. This paper analyses FAO initiatives in the framework of the evolution of the nutritional situation in developing countries and identifies national and regional contexts in which technical solutions may be successful, as well as those requiring the implementation of economic, political and social measures.
\end{abstract}

World food situation: Developing countries: Nutrition

Since the founding of the Food and Agriculture Organization of the United Nations in 1946, it has reported on the serious problem of hunger in the world. The First World Food Survey, conducted that same year by the FAO, revealed that two-thirds of the world's population suffered from hunger, and pointed to a net transfer of food from undernourished countries to industrialized countries. One of the FAO's first proposals for resolving this grave situation was the creation of a World Food Council that would be given responsibility for handling the world's food reserves and financing the placement of surplus food in the countries with the greatest need. This Council was never consolidated, however. In 1952, the FAO conducted the Second World Food Survey, which confirmed the serious world situation, and documented the deterioration in this regard in the poorest countries (De Castro, 1974).

During the 1960s, a new juncture in international economic relations prompted the agricultural technification of developing countries. Ironically, this process-far from signifying an improvement in the food and nutrition situation for the poor populations in these countries-frequently led to a deterioration of their situation and to consecutive agricultural crises, with the substitution of staple food crops with highly technified commercial crops destined for use as inputs in transnational food industries (Estevez \& Portilla, 1980). However, the growth in agricultural productivity sparked the hope that food sufficiency facilitated by agricultural modernization would, on its own, resolve the problem of hunger on the planet (Pearson, 1969). Taking into consideration the cost of the necessary food for covering the deficit in energy requirements for undernourished children in the world, the then World Bank president, Robert McNamara, said in 1971 that the eradication of child malnutrition in the world would have a cost of only eight dollars a year per child.
In November 1974, at the World Food Conference organized by the UN in Rome, the goal of eradicating hunger on the face of the earth by 1984 was established. The final declaration of the Conference made the commitment that 'within a decade, no child will go to bed hungry, no family will fear for its next day's bread, and no human being's future and capacities will be stunted by malnutrition' (Organización de las Naciones Unidas, 1974). Such optimism was founded on a projected increase in the production of food for human consumption on the planet, from 10.04 to 10.88 MJ (2400 to $2600 \mathrm{kcal})$ per inhabitant over the course of a decade. This would make it possible to satisfy, with a very reasonable margin of confidence, the energy and nutrient needs for all the planet's inhabitants. The production goals were fully achieved, with $11.09 \mathrm{MJ}$ (2650 kcal) produced per inhabitant. Nevertheless, compliance with the goals for eradicating malnutrition became a more distant possibility, with hunger experienced in vast regions of the planet, and an increase in malnutrition in developing countries.

In 1996, the FAO organized a World Food Summit 'in response to the continued existence of widespread undernutrition and growing concern about the capacity of agriculture to meet future food needs'. In that year, world food availability was already at $11.59 \mathrm{MJ}(2770 \mathrm{kcal})$, although in the 64 countries with the lowest incomes and where two-thirds of the world population is concentrated, food availability was equivalent to only 10.04 MJ (2400 kcal; Food and Agriculture Organization, 1999).

The 1996 World Summit established the goal of reducing the number of undernourished people by half, from 800 to 400 million, over the following 20 years. Five years later, a total reduction of only 19 million had been registered, and, furthermore, not only a decrease in the rate of reducing 
hunger had become apparent, but also an increase in the undernourished population in critical areas such as sub-Saharan Africa and India (Food and Agriculture Organization, 2003). In the most recent FAO report on the status of food insecurity in the world, it is acknowledged that over the last 5 years the number of undernourished persons has increased by nearly four million a year. All this indicates that, once again, it will be impossible to meet the proposed goal unless vigorous measures are taken to radically modify the current tendencies.

The incapacity to eradicate the serious problem of hunger and chronic malnutrition on the planet is contradictory if we consider that, since 1974, a notorious increase has been observed not only in world food production, but also in food availability at the national level even in the poorest countries, with only some extreme exceptions. Developing countries have increased the per capita availability of food energy by $24 \%$ and of proteins by $32 \%$, and even the availability of animal proteins has doubled, from 10 to 20 daily grams per capita (Food and Agriculture Organization, 2004). Another notorious paradox can be observed when we analyse recent tendencies in food and nutrition conditions in regions and countries where there is a high prevalence of malnutrition; specifically the emergence of serious problems of obesity in the poor population, with serious health consequences (Peña \& Bacallao, 2000).

The UN classifies 50 countries as developed, including European countries, the majority of the former Soviet Union nations, plus Canada, the USA, Australia, New Zealand, South Africa, Japan and Israel. It classifies the rest of the countries as developing, with a common denominator of per capita income that is lower than \$US 17000 . These approximately 180 countries have a total population of 4.5 billion persons, and their food and nutritional problems differ significantly. For the purpose of analysis, it is convenient to operationally subdivide these countries according to their geographic location: Latin America, sub-Saharan Africa, Southeast Asia, the Near East and North Africa, China and India, as well as by economic development achieved, measured by per capita income: low income (less than \$US 750), low medium income (\$US 750-3000), high medium income (from \$US 3000-9200) and high income (above \$US 9200).

Of the undernourished population, 135 million are concentrated in China, 214 million in India, 198 million in subSaharan Africa, and 156 million in the other Asian and Pacific countries. There are 53 million in Latin America, and 85 million in other countries of the world, including 10 million who reside in high-income developed countries (Food and Agriculture Organization, 2003). Another pertinent criterion for classifying countries is national food availability, estimated, for example, by per capita energy availability: $<8.37$ MJ $(<2000$ kcal $) ; 8.37-10.04$ MJ (2000-2400 kcal); 10.04-10.88 MJ (2400-2600 kcal); 10.88-12.55 MJ (2600-3000 kcal); and >12.55 MJ ( $>3000$ kcal). Finally, another criterion proposed is in relation to the percentage of the population that is undernourished: less than 5\%; from 5 to $19 \%$; from 20 to $34 \%$; and more than $35 \%$.

The distribution of developing countries according to this multidimensional classification matrix (Table 1) denotes diverse scenarios manifesting the level of efficiency in the use of recourses, the unequal distribution of wealth, the effectiveness of programmes for fighting malnutrition, and the prevention of obesity and non-transmissible chronic illnesses:

- Countries in conditions of extreme poverty, with deterioration in food production and political crises, with no possibility of economic development in the short or medium term that will allow them to satisfy the minimal nutritional requirements of their populations, and for which the only immediate alternative for alleviating the situation of hunger is international aid (Sierra Leone, Congo, Somalia, Afghanistan and Burundi, among others).

- Low-income countries that have improved in terms of food availability; however, they have not been able to decrease the prevalence of malnutrition (sub-Saharan Africa). In these countries, malnutrition is frequently associated with serious social inequalities; unhealthy conditions; epidemics such as HIV/AIDS, malaria, respiratory and gastrointestinal infections; minimal health services; and the economic incapacity of broad sectors of the population to access the existing food. These countries require vigorous action to comprehensively fight poverty through rational policies of income transfer, creation of productive, health and educational infrastructure, efficient use of available resources at a local level, and direct food aid.

- Countries that have made efficient use of available health and food resources, and have achieved significant progress in coming closer to the eradication of child malnutrition (Costa Rica, Chile, Cuba and Thailand, for example).

- Countries that have increasing economic and food resources; some with substantial improvements in reducing malnutrition (China, India), and others with minimal progress in reducing the prevalence of malnutrition in broad sectors of the marginalized population, and which are already confronting a serious epidemic of obesity and chronic illnesses associated with relative overnutrition as a consequence of intense changes in eating patterns and life-styles (Mexico, Brazil, Egypt).

The current challenge consists of developing a theoreticalconceptual model for articulating the logic of the different processes observed, and determining their causes and development as the interaction of political, economic, cultural and technological processes in a globalized world, in which the processes of demographic, epidemiological and nutritional transition make up a highly complex system that is impossible to understand through only linear mechanisms of agricultural productivity (Popkin, 2004), the expansion of health services and nutritional education. The understanding of these processes is indispensable for formulating viable actions and programmes that will make it possible to overcome decades of repeated failures to improve or avoid the deterioration in the health and nutritional conditions in developing countries.

An initial element for constructing a theoretical-conceptual model for an objective understanding of the nutritional dynamics of the planet requires moving beyond the naive productivist vision that conceives of hunger and malnutrition as merely problems of insufficient food, due to low agricultural productivity. As of 2002, world food availability already surpassed daily per capita levels of $11.72 \mathrm{MJ}(2800 \mathrm{kcal})$ and $75 \mathrm{~g}$ of protein-more than sufficient for satisfying the requirements of all the planet's inhabitants. The lack of a linear relationship 
Table 1. Distribution of developing countries according to dietary energy supply, child mortality, malnutrition and gross national income (GNI)

\begin{tabular}{|c|c|c|c|c|c|c|}
\hline Country & $\begin{array}{c}\text { Total } \\
\text { population } \\
\text { (millions)* }^{\star}\end{array}$ & $\begin{array}{c}\text { Dietary } \\
\text { energy supply } \\
\text { per capita } \\
(\mathrm{kcal} / \mathrm{d}) \dagger \ddagger\end{array}$ & $\begin{array}{l}\text { Under-five } \\
\text { mortality rate } \\
\text { (per } 1000 \\
\text { live births)§ }\end{array}$ & $\begin{array}{c}\text { Under-five } \\
\text { underweight } \\
\text { moderate \& } \\
\text { severe (\%)§ }\end{array}$ & $\begin{array}{c}\text { GNI per } \\
\text { capita (\$US)\| }\end{array}$ & $\begin{array}{c}\text { GNI parity } \\
\text { purchasing power } \\
\text { (international \$)\| }\end{array}$ \\
\hline \multicolumn{7}{|c|}{ Countries in conditions of extreme poverty, with deterioration in food production and political crises } \\
\hline Burundi & 7 & 1610 & 190 & 45 & 100 & 620 \\
\hline Dem. Rep. of the Congo & 52 & 1570 & 205 & 34 & 100 & 640 \\
\hline Ethiopia & 67 & 1910 & 172 & 47 & 100 & 710 \\
\hline Liberia & 3 & 2080 & 235 & 27 & 140 & NA \\
\hline Sierra Leone & 5 & 1930 & 316 & 27 & 150 & 530 \\
\hline Malawi & 11 & 2170 & 183 & 25 & 170 & 600 \\
\hline Tajikistan & 6 & 1720 & 116 & NA & 190 & 1040 \\
\hline Eritrea & 4 & 1670 & 111 & 44 & 190 & 1110 \\
\hline Niger & 11 & 2130 & 265 & 40 & 200 & 820 \\
\hline Mozambique & 18 & 1950 & 197 & 26 & 210 & 1070 \\
\hline Rwanda & 8 & 2000 & 183 & 24 & 220 & 1290 \\
\hline Chad & 8 & 2150 & 200 & 28 & 250 & 1100 \\
\hline United Rep. of Tanzania & 35 & 1970 & 165 & 29 & 290 & 610 \\
\hline Madagascar & 16 & 2070 & 136 & 40 & 290 & 800 \\
\hline Mali & 11 & 2370 & 231 & 33 & 290 & 960 \\
\hline Burkina Faso & 12 & 2460 & 197 & 34 & 300 & 1180 \\
\hline Cambodia & 12 & 1970 & 138 & 45 & 310 & 2060 \\
\hline Zambia & 10 & 1900 & 202 & 24 & 380 & 850 \\
\hline Kenya & 31 & 2040 & 122 & 22 & 390 & 1020 \\
\hline Yemen & 19 & 2050 & 107 & 46 & 520 & 820 \\
\hline Congo & 4 & 2210 & 108 & 14 & 640 & 710 \\
\hline Angola & 13 & 1900 & 260 & 31 & 710 & 1890 \\
\hline Afghanistan & 3 & 1630 & 257 & 49 & NA & NA \\
\hline Somalia & 9 & 1600 & 225 & 26 & NA & NA \\
\hline Iraq & 24 & 2150 & 133 & 16 & NA & NA \\
\hline \multicolumn{7}{|c|}{ Low-income countries that have improved in terms of food availability, but not been able to decrease the prevalence of malnutrition } \\
\hline Nigeria & 133 & 2770 & 183 & 31 & 320 & 900 \\
\hline Mauritania & 3 & 2730 & 183 & 32 & 430 & 2010 \\
\hline Côte d'Ivoire & 17 & 2590 & 175 & 21 & 660 & 1390 \\
\hline Togo & 5 & 2310 & 141 & 25 & 310 & 1500 \\
\hline Senegal & 10 & 2280 & 138 & 23 & 550 & 1660 \\
\hline Lesotho & 2 & 2310 & 132 & 18 & 590 & 3120 \\
\hline Uganda & 25 & 2370 & 124 & 23 & 240 & 1440 \\
\hline Haiti & 8 & 2040 & 123 & 17 & 380 & 1630 \\
\hline Zimbabwe & 13 & 2100 & 123 & 13 & 480 & 2180 \\
\hline Botswana & 2 & 2270 & 110 & 13 & 3430 & 7960 \\
\hline Pakistan & 145 & 2460 & 109 & 38 & 470 & 2060 \\
\hline Myanmar & 49 & 2810 & 109 & 28 & NA & NA \\
\hline Sudan & 33 & 2290 & 107 & 34 & 460 & 1880 \\
\hline Lao People's Dem. & 6 & 2280 & 100 & 40 & 320 & 1730 \\
\hline Ghana & 20 & 2620 & 100 & 25 & 320 & 2190 \\
\hline Kazakhstan & 15 & 2360 & 99 & 4 & 1780 & 6170 \\
\hline Azerbaijan & 8 & 2380 & 96 & 17 & 810 & 3380 \\
\hline Papua New Guinea & 5 & 2180 & 94 & 35 & 510 & 2240 \\
\hline India & 1049 & 2490 & 93 & 47 & 530 & 2880 \\
\hline Nepal & 24 & 2440 & 91 & 48 & 240 & 1420 \\
\hline Turkmenistan & 5 & 2760 & 87 & 12 & 1120 & 5840 \\
\hline Bangladesh & 136 & 2160 & 77 & 52 & 400 & 1870 \\
\hline Bolivia & 9 & 2240 & 77 & 8 & 890 & 2450 \\
\hline Mongolia & 2 & 2070 & 76 & 13 & 480 & 1800 \\
\hline Uzbekistan & 25 & 2270 & 68 & 19 & 420 & 1720 \\
\hline Namibia & 2 & 2700 & 67 & 24 & 1870 & 6620 \\
\hline Kyrgyzstan & 5 & 2860 & 61 & 11 & 330 & 1660 \\
\hline Guatemala & 12 & 2160 & 58 & 24 & 1910 & 4060 \\
\hline Dem. People's Rep. Korea & 22 & 2180 & 55 & 28 & NA & NA \\
\hline El Salvador & 6 & 2460 & 39 & 12 & 2200 & 4890 \\
\hline Honduras & 7 & 2400 & 38 & 17 & 970 & 2580 \\
\hline Viet Nam & 80 & 2500 & 38 & 34 & 480 & 2490 \\
\hline Philippines & 80 & 2370 & 38 & 32 & 1080 & 4640 \\
\hline
\end{tabular}


Table 1. Continued

\begin{tabular}{|c|c|c|c|c|c|c|}
\hline Country & $\begin{array}{c}\text { Total } \\
\text { population } \\
\text { (millions) }^{*}\end{array}$ & $\begin{array}{c}\text { Dietary } \\
\text { energy supply } \\
\text { per capita } \\
\text { (kcal/d)†‡ }\end{array}$ & $\begin{array}{l}\text { Under-five } \\
\text { mortality rate } \\
\text { (per } 1000 \\
\text { live births)§ }\end{array}$ & $\begin{array}{l}\text { Under-five } \\
\text { underweight } \\
\text { moderate \& } \\
\text { severe }(\%) \S\end{array}$ & $\begin{array}{l}\text { GNI per } \\
\text { capita (\$US)\| }\end{array}$ & $\begin{array}{c}\text { GNI parity } \\
\text { purchasing power } \\
\text { (international \$)\| }\end{array}$ \\
\hline \multicolumn{7}{|c|}{ Countries that have made efficient use of available health and food resources, closer to the eradication of child malnutrition } \\
\hline Cuba & 11 & 2610 & 9 & 4 & NA & NA \\
\hline Thailand & 62 & 2470 & 23 & 18 & 2190 & 7450 \\
\hline Uruguay & 3 & 2840 & 16 & 4 & 3790 & 7980 \\
\hline Costa Rica & 4 & 2760 & 11 & 5 & 4280 & 9040 \\
\hline Chile & 16 & 2850 & 12 & 1 & 4390 & 9810 \\
\hline Bosnia and Herzegovina & 4 & 2730 & 18 & 4 & 1540 & 6320 \\
\hline Bulgaria & 8 & 2630 & 16 & NA & 2130 & 7610 \\
\hline Croatia & 4 & 2620 & 8 & 1 & 5350 & 10710 \\
\hline Slovakia & 5 & 2910 & 9 & NA & 4920 & 13420 \\
\hline Kuwait & 2 & 3150 & 10 & 2 & 16340 & 17870 \\
\hline \multicolumn{7}{|c|}{ Countries that have increasing economic and food resources with substantial improvements in reducing malnutrition } \\
\hline Armenia & 3 & 2000 & 35 & 3 & 950 & 3770 \\
\hline Nicaragua & 5 & 2250 & 43 & 10 & 730 & 2400 \\
\hline Georgia & 5 & 2290 & 29 & 3 & 830 & 2540 \\
\hline Dominican Rep. & 9 & 2320 & 47 & 5 & 2070 & 6210 \\
\hline Sri Lanka & 19 & 2330 & 19 & 33 & 850 & 3730 \\
\hline Venezuela & 25 & 2336 & 21 & 4 & 3490 & 4740 \\
\hline Paraguay & 6 & 2560 & 30 & 5 & 1100 & 4740 \\
\hline Colombia & 44 & 2570 & 23 & 7 & 1810 & 6520 \\
\hline Peru & 27 & 2600 & 39 & 7 & 2150 & 5090 \\
\hline Macedonia & 2 & 2660 & 26 & 6 & 1980 & 6720 \\
\hline Jamaica & 3 & 2690 & 20 & 4 & 2760 & 3790 \\
\hline Serbia and Montenegro & 8 & 2720 & 19 & 2 & 1400 & NA \\
\hline Ecuador & 13 & 2740 & 30 & 14 & 1790 & 3440 \\
\hline Latvia & 2 & 2790 & 21 & NA & 4070 & 10130 \\
\hline Saudi Arabia & 22 & 2840 & 28 & 14 & 8530 & 12850 \\
\hline Iran, Islamic Rep. & 66 & 2930 & 42 & 11 & 2000 & 7190 \\
\hline China & 1280 & 2970 & 39 & 10 & 1100 & 4990 \\
\hline \multicolumn{7}{|c|}{$\begin{array}{l}\text { Countries that have increasing food resources, malnutrition in broad sectors of the marginalized population, and serious epidemic } \\
\text { of obesity and chronic illnesses }\end{array}$} \\
\hline Argentina & 36 & 3180 & 19 & 5 & 3650 & 10920 \\
\hline Lebanon & 4 & 3170 & 32 & 3 & 4040 & 4840 \\
\hline Mexico & 101 & 3150 & 29 & 8 & 6230 & 8950 \\
\hline Syrian Arab Rep. & 17 & 3040 & 28 & 7 & 1160 & 3430 \\
\hline Morocco & 30 & 3000 & 44 & 9 & 1320 & 3950 \\
\hline Brazil & 174 & 3000 & 36 & 6 & 2710 & 7480 \\
\hline Algeria & 31 & 2970 & 49 & 6 & 1720 & 5940 \\
\hline Indonesia & 212 & 2900 & 45 & 25 & 810 & 3210 \\
\hline Jordan & 5 & 2740 & 33 & 5 & 1850 & 4290 \\
\hline
\end{tabular}

NA, not available.

*United Nations (2001).

† To convert to from $\mathrm{kcal} / \mathrm{d}$ to $\mathrm{MJ} / \mathrm{d}$, multiply value by 0.004184 .

$\ddagger$ Food and Agriculture Organization (2004).

§UNICEF (2005).

|| World Bank (2004)

between hunger and food availability has been extensively documented, and indeed, such a relationship has been found between hunger and the capacity to access food on the part of socially marginalized sectors. It is not uncommon for an increase in agricultural production to be accompanied by serious environmental deterioration, the impoverishment of small farmers and, consequently, an increase in the malnourished population and in food insecurity (García \& Escudero, 1982; George, 1986).

Nor should we underestimate the geopolitical dimension and economic interests associated with malnutrition and poor eating. In the logic of food production and financing, priority is given to company profits and political interests.
The war in Iraq has cost the USA alone, as of December 2004, more than \$ US150 billion, or in other words, the cost of all the programmes to fight world hunger during a period of 6 years.

There is no doubt that the world has more than the necessary technical, economic and food resources to eradicate malnutrition from the face of the earth. The efficient and rational use of these resources in the context of national programmes has demonstrated a great capacity for decreasing malnutrition in the short term in the countries where there is a minimum of food security and sufficiency, together with the political will of the corresponding governments to confront the problem. Nevertheless, in the world context, the solution to the problem 
of hunger demands a firm commitment on the part of all governments and all international entities to technically efficient comprehensive programmes, subsidies and intelligent financing, but also to democracy; equitable distribution of wealth; transparency and honesty in the use of public resources; and the guarantee, respect and protection for the right to food and all economic, social and cultural rights recognized by the UN.

\section{References}

De Castro J (1974) El Hambre, Problema Universal. Buenos Aires: La Pléyade.

Estevez J \& Portilla B (1980) El Hambre, Reflejo Crítico del Sistema Alimentario Mundial. México: Centro de Estudios Económicos y Sociales del Tercer Mundo.

Food and Agriculture Organization (1999) The State of Food Insecurity in the World, 1999. Rome: FAO.

Food and Agriculture Organization (2003) The State of Food Insecurity in the World, 2003. Rome: FAO.
Food and Agriculture Organization (2004) Food Balance Sheets. FAOSTAT 2004 (CD-ROM). Rome: FAO.

García R \& Escudero J (1982) The Constant Catastrophe: Malnutrition, Famines and Drought. Vol 2: Drought and Man. Oxford: Pergamon Press.

George S (1986) How the Other Half Dies: The Real Reasons for World Hunger. Harmondworth: Penguin Books.

Organizacion de las Naciones Unidas (1974) Informe de la Conferencia Mundial de la Alimentación. Roma: ONU.

Pearson L (1969) El Desarrollo Empresa Común. Informe de la Comisión de Desarrollo Internacional. Madrid: Tecnos.

Peña M \& Bacallao J (2000) Obesity and Poverty: A New Public Health Challenge. Washington, DC: Pan American Health Organization.

Popkin BM (2004) The nutrition transition: an overview of world patterns of change. Nutr Rev 62, S140-S143.

United Nations (2001) World Population Prospects: The 2000 Revision. New York: UN.

UNICEF (2005) State of the World's Children 2005. New York: UNICEF.

World Bank (2004) World Development Indicators 2004. New York: World Bank. 